\title{
The protective role of copper-zinc superoxide dismutase against alloxan-induced diabetes: morphological aspects
}

\author{
L.G.Thaete ${ }^{1}$, R. K. Crouch ${ }^{2}$, M. G. Buse ${ }^{3}$ and S.S. Spicer ${ }^{1}$ \\ ${ }^{1}$ Departments of Pathology, ${ }^{2}$ Ophthalmology and Biochemistry, ${ }^{3}$ Medicine and Biochemistry, Medical University of South Carolina, Charleston, \\ USA
}

\begin{abstract}
Summary. Copper-zinc superoxide dismutase is known to protect pancreatic $\beta$-cell function from the damage of alloxan. A morphological investigation of copper-zinc superoxide dismutase prophylaxis against alloxan was undertaken in rats to investigate the mechanism of this protective action. Exogenous copper-zinc superoxide dismutase reproducibly protected the morphological features of pancreatic $\beta$ cells against damage by alloxan as determined by light microscopic immunostaining for insulin and by ultrastructural examination. By the same criteria, $\alpha$ and $\delta$ cells appeared unaffected by admin-
\end{abstract}

istration of a combination of alloxan and copper-zinc superoxide dismutase or either agent alone. Autoradiography after injection of ${ }^{125} \mathrm{I}$ labelled copper-zinc superoxide dismutase into normal rats showed no evidence that the enzyme enters viable islet cells, suggesting an extracellular site of protection against alloxan.

Key words: Alloxan, superoxide dismutase, islets of Langerhans, diabetes.
The chemical agent alloxan has been used extensively as an experimental model for diabetes mellitus in animals, as it exhibits highly selective cytotoxicity for the pancreatic beta cells [1]. Several investigators suggested that the diabetogenic action of alloxan is mediated by the generation of toxic oxygen containing species [2-7]. These likely include $\mathrm{H}_{2} \mathrm{O}_{2}$, formed during the autooxidation of dialuric acid and the more toxic $\mathrm{OH}^{-}$radical generated from the metal-catalysed Haber-Weiss reaction [7].

Copper-zinc superoxide dismutase (CuZn SOD, superoxide oxidoreductase, EC 1.15.1.1), an enzyme which scavenges the toxic superoxide anion, is present in cells of the islets of Langerhans [8-10]. The diabetogenic action of alloxan has been shown to be attenuated in vitro and in vivo by CuZn SOD and other oxygen radical scavengers [11-13]. In contrast to $\mathrm{CuZn}$ SOD, cyanide inactivated SOD did not protect islets against alloxan, suggesting that the protective effect was dependent upon enzymatic activity [14].

By bioassay and by radioimmunoassay of both $\mathrm{CuZn}$ and Mn-SOD the SOD content of islets in rodents is relatively low when compared to other tissues [15]. However, by immunostaining, canine and human islets appear to be richer in CuZn SOD than the exocrine pancreas [8-10], yet the CuZn SOD content of human pancreas is about average as compared to other tissues [16]. In addition to damaging islets directly via released oxygen radicals, alloxan may inhibit the enzyme activity of $\mathrm{CuZn}$ SOD of tissues [17] including islets.
Several authors have reported the ultrastructural morphological effects of diabetogenic doses of alloxan on cells of the islets of Langerhans. The earliest change noted is a general swelling of $\beta$ cells [18]. An initial increase in granulation of $\beta$ cells is followed by dissolution of the granules. Vacuole formation, mitochondrial swelling, nuclear pyknosis, and disintegration of the cell membrane all occur within $2 \mathrm{~h}$ after alloxan treatment. $\alpha$ and $\delta$ cells, on the other hand, appear unaffected by alloxan. Such results have been published for the dog [19], rabbit [20-22], mouse [23], rat [24], hamster [25], and bat [26]. However, the fine structural changes in islets from animals protected with SOD from the diabetic effects of alloxan treatment have not been investigated. Such information would serve to elucidate the mechanism of protection of SOD and the mode of action of alloxan. The present study compares the fine structure of pancreatic islets in rats exposed to alloxan with and without CuZn SOD and undertakes to determine by autoradiography of labelled SOD the distribution of the injected enzyme and its possible site of action.

\section{Materials and methods}

\section{Treatment of animals}

Male Wistar rats (100-200 g) were fasted for $18 \mathrm{~h}$ before treatment with alloxan. Four experimental groups $(n=5-11)$ received, by injection via the tail vein, one of the following, each in $0.5 \mathrm{ml}$ sterile phosphate-buffered saline (PBS): (1) $50 \mathrm{mg} / \mathrm{kg}$ freshly dissolved alloxan 

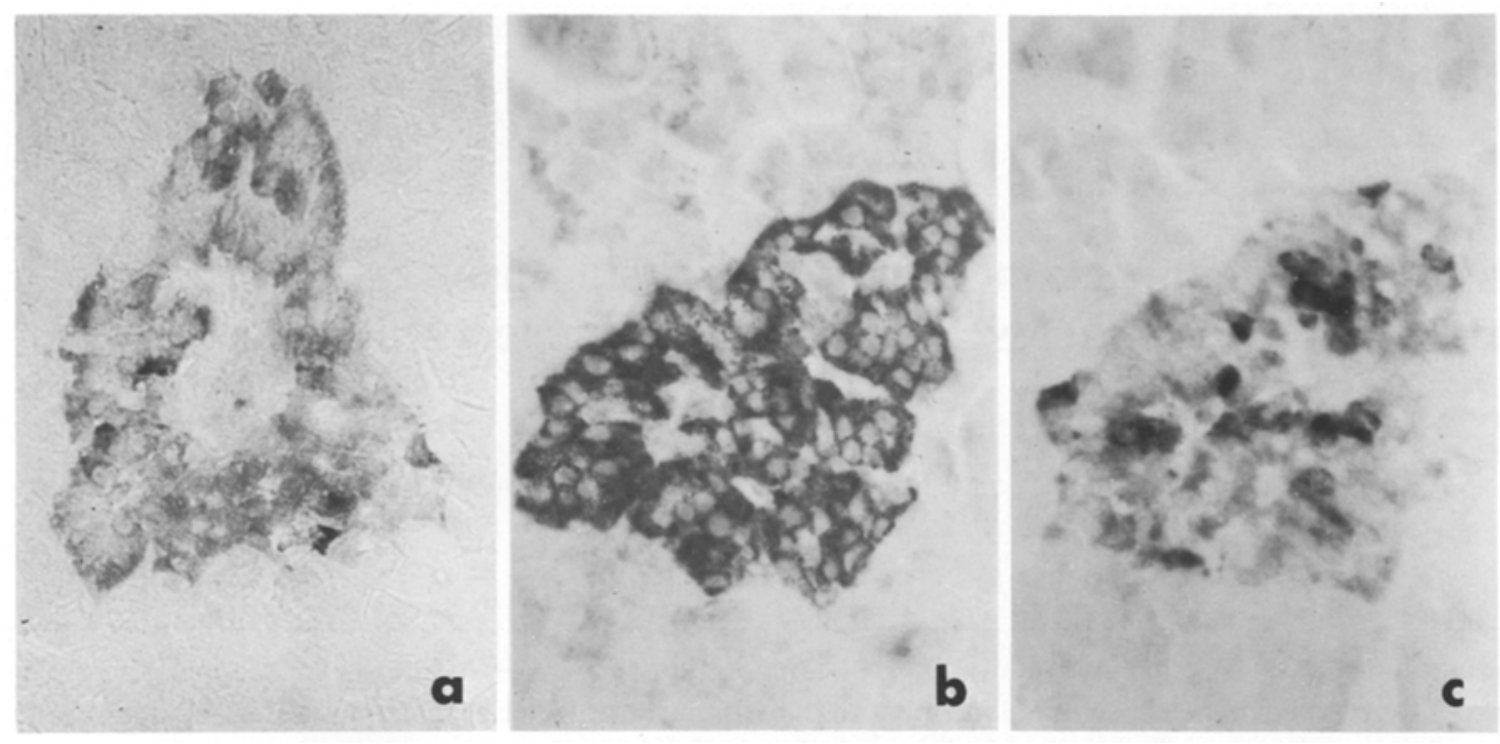

Fig. 1a-c. Adjacent sections of a rat islet 5 days after alloxan treatment. a a section immunostained for insulin, only a few $\beta$ cells remain $(\times 80)$. b Staining for glucagon shows $\alpha$ cells throughout the islets in contrast to their typical peripheral location normally $(\times 80)$ ca section stained for somatostatin: a typical complement of $\delta$ cells persists in this islet. This staining pattern is similar to control islets stained for somato$\operatorname{statin}(\times 80)$
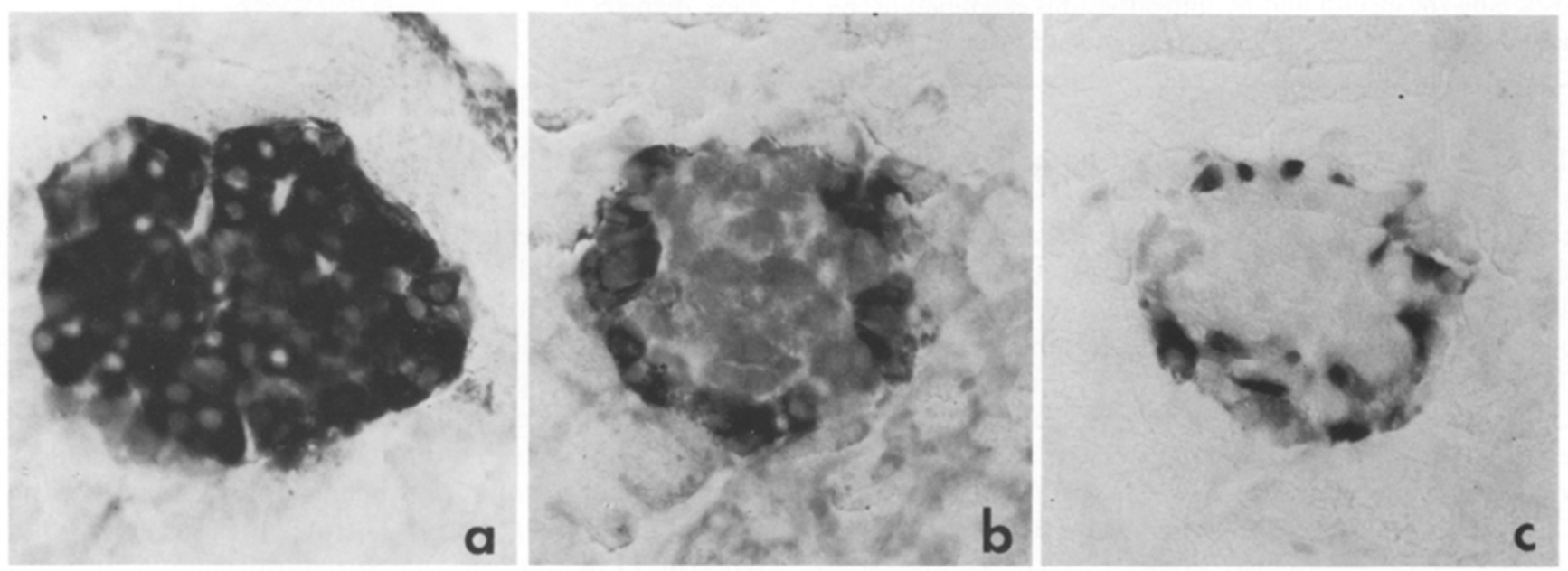

Fig. 2 a-c. Adjacent sections of a rat islet 5 days after treatment with CuZn SOD and alloxan. a Insulin immunolocalization reveals a typical complement of $\beta$ cells occupying most of the central portion of the islet $(\times 400)$. b Immunoreactivity for glucagon is located in a normal pattern in $\alpha$ cells surrounding the beta cell population instead of throughout the islet as observed after alloxan without CuZn SOD (cf. Fig. 1b) $(\times 400)$. c Somatostatin immunostaining shows a discontinuous ring of $\delta$ cells at the periphery of the islet $(\times 400)$; similar staining patterns were observed in islets from control and $\mathrm{CuZn}$ SOD-treated animals

monohydrate (Sigma, St.Louis, Missouri); (2) buffer alone; (3) $35 \mathrm{mg} / \mathrm{kg}$ canine CuZn SOD (Sigma) and (4) $35 \mathrm{mg} / \mathrm{kg}$ canine CuZn SOD followed by $50 \mathrm{mg} / \mathrm{kg}$ alloxan monohydrate in $15 \mathrm{~min}$. For SOD autoradiography, $80 \mu \mathrm{Ci}$ of the iodinated enzyme was administered via tail vein in $1 \mathrm{ml}$ PBS to six rats of about $100 \mathrm{~g}$ weight. All animals were anaesthetised by methoxyflurane vapor (Metofane, PitmanMoore, Washington Crossing, New Jersey) before injection and killed by cervical dislocation. Animals from each group $(n=3-5)$ were killed at $30 \mathrm{~min}$ or 5 days after injection. Blood samples were drawn from the vena cava for glucose analysis on a Glucose Analyzer 2 (Beckman, Norcross, Georgia), and samples of pancreas were collected and prepared for both light microscope immunocytochemistry and electron microscopy. For autoradiography, animals were killed 10, 50 or $120 \mathrm{~min}$ post-injection.

\section{Iodinated $S O D$}

Bovine CuZn SOD was labelled with ${ }^{125} \mathrm{I}$ by the chloramine-T method [27], and separated from unbound ${ }^{125} \mathrm{I}$ on a G-50 Sephadex column. The product was identified as ${ }^{125}$ I-SOD by polyacrylamide gel electrophoresis $(7.5 \%)$, followed by staining for SOD enzymatic activity [28, 29]. Serial gel slices $(5 \mathrm{~mm})$ were counted; radioactivity was associated exclusively with the SOD band. ${ }^{125}$ I-SOD was diluted with carrier SOD to yield a specific activity of $12.5 \mathrm{mCi} / \mathrm{mg}$.

\section{Histologic preparation and immunocytochemical staining}

Tissue sections of pancreas ( $1-2 \mathrm{~mm}$ thick) were immersed $2 \mathrm{~h}$ in $4 \%$ paraformaldehyde buffered with $2 \%$ calcium acetate, rinsed in run- 


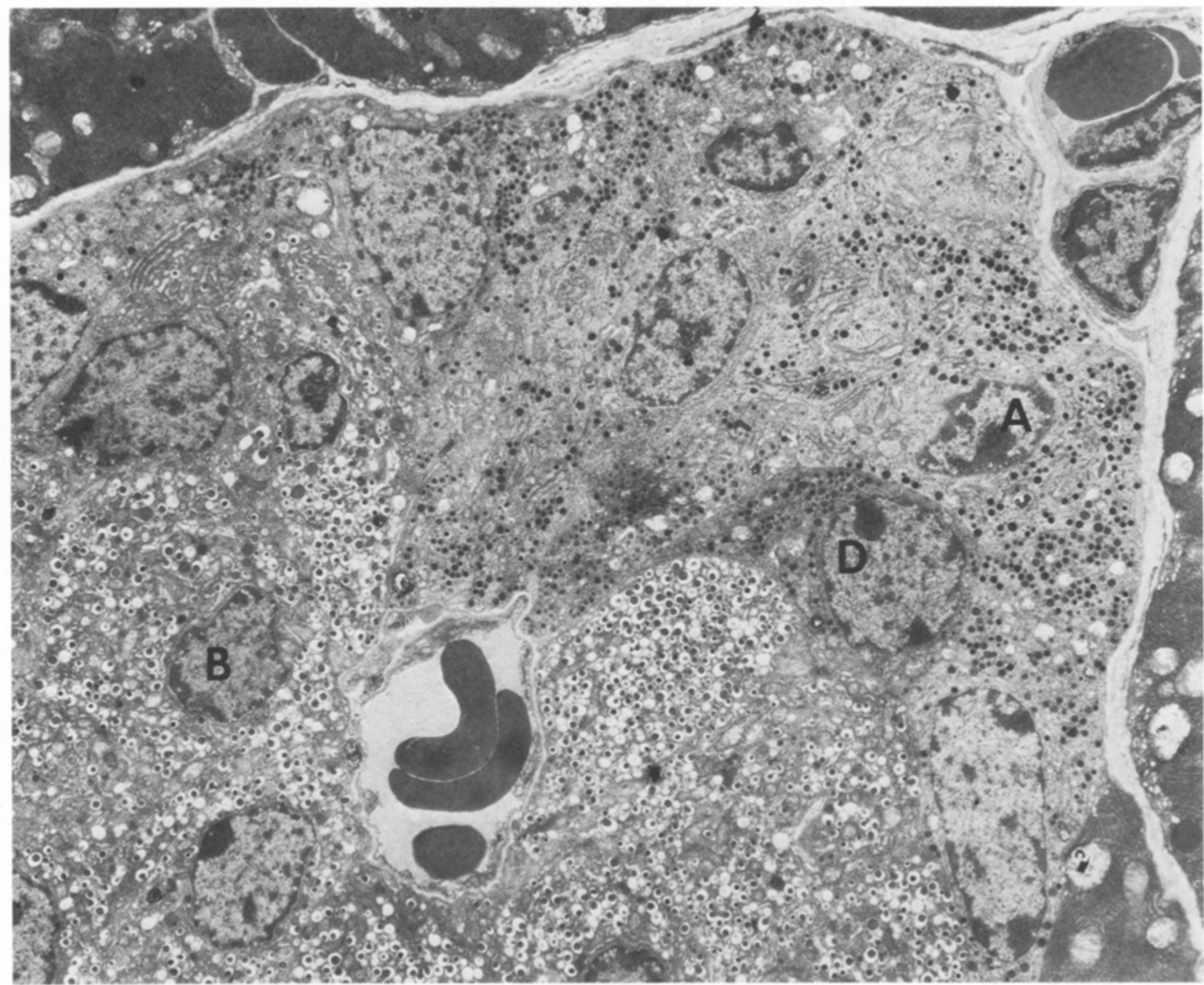

Fig.3. In an islet 5 days after treatment with $\mathrm{CuZn}$ SOD and alloxan, typical profiles of $\alpha$ (A, dense, thin-rimmed granules), $\beta$ (B, dense, widerimmed granules), and $\delta(\mathrm{D}$, moderately-dense, rimless granules) cells are present. These cell types exhibited the same morphological characteristics in islets from control and $\mathrm{CuZn} \mathrm{SOD-treated} \mathrm{animals}(\times 4,000)$

ning water for $2 \mathrm{~h}$ to remove excess formalin, dehydrated through a graded series of ethyl alcohols and embedded in paraffin. Adjacent sections were stained immunocytochemically by a modified immunoenzyme bridge technique $[30,31]$ which employed the avidin-biotinperoxidase complex (ABC, Vector Labs., Burlingame, California) method [31], described in detail elsewhere [10]. Antisera against glucagon, insulin, and somatostatin (Dako Corp., Santa Barbara, California) were used to identify $\alpha, \beta$ and $\delta$ cells, respectively.

Portions of pancreas were also prepared for electron microscopic examination. Ten pieces $\left(1 \mathrm{~mm}^{3}\right)$ from the tail of the pancreas from each animal were fixed $2 \mathrm{~h}$ in $2.5 \%$ glutaraldehyde in $0.1 \mathrm{M}$ phosphate buffer ( $\mathrm{pH} 7.2$ ), post-fixed $1 \mathrm{~h}$ in $2 \% \mathrm{OsO}_{4}$ in phosphate buffer, rinsed, dehydrated, and embedded in Epon 812. Islets were identified in thick sections, then thin-sectioned, stained with uranyl acetate and lead citrate [32], and photographed in an electron microscope (model 100-S, JEOL, Tokyo, Japan).

For autoradiography, lung, liver, kidney and pancreas were fixed and processed for localization of labelled enzyme at the light and electron microscopic level by standard methods [33].

\section{Results}

Five days after injection, animals which received only alloxan showed fasting blood glucose levels of $27.1 \pm$
$2.2 \mathrm{mmol} / 1$. This level contrasted with that of $3.90 \pm$ $0.31 \mathrm{mmol} / 1$ for saline controls, $4.84 \pm 0.55 \mathrm{mmol} / 1$ for the SOD injection group and $3.08 \pm 0.55 \mathrm{mmol} / 1$ for the rats receiving SOD and alloxan.

Immunostaining of pancreatic islets for insulin, glucagon, and somatostatin in alloxan-diabetic animals (Fig. 1) revealed a near absence of insulin 5 days following alloxan treatment, accompanied by a broadening pattern of glucagon staining throughout the islet. The proportion of somatostatin-positive cells appeared unchanged throughout the time period studied. Islets from SOD-treated animals and those which received both SOD and alloxan exhibited immunostaining for insulin, glucagon, and somatostatin which was the same as in control animals (Fig. 2).

At the electron microscopic level, following treatment with alloxan, many $\beta$-cells showed extensive pathological changes at $30 \mathrm{~min}$. Some cells contained an apparently increased population of secretion granules, others showed vacuolation of the rough endoplasmic reticulum and disrupted architecture. $\alpha$ and $\delta$ cells 


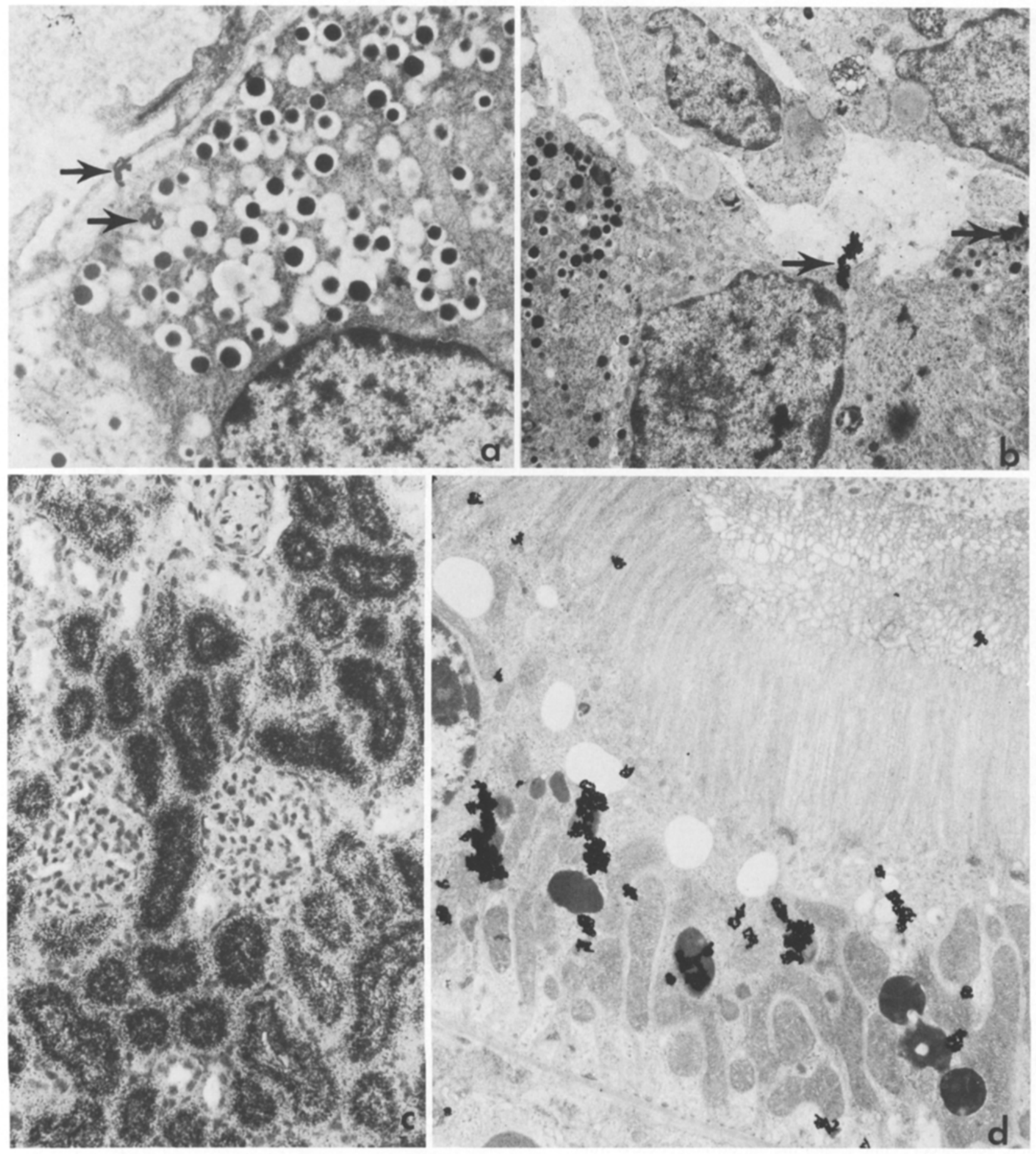

Fig.4a-d. Radioautographic localization of radioiodine in sections of kidney and pancreas from rats injected with ${ }^{125} \mathrm{I}-\mathrm{CuZn}$ SOD. a Pancreatic $\beta$ cells in an islet of Langerhans from an animal treated with ${ }^{125} \mathrm{I}-\mathrm{CuZn}$ SOD. At $10 \mathrm{~min}$ following intravenous injection of the labelled enzyme, radioautographic grains (arrows) are visible on or near the cell membrane but not within $\beta$ cells, indicating exclusion of CuZn SOD from the interior of these cells $(\times 10,000)$; b Several cell profiles from another islet treated with ${ }^{125} \mathrm{I}-\mathrm{CuZn}$ SOD are visible in this electron micrograph. Radioautographic grains (arrows) are located over the plasmalemma of $\beta$ cells. $(\times 6,000)$; $\mathbf{c}$ A section from the cortex of the kidney reveals heavily labelled proximal convoluted tubules around two unlabelled glomeruli. $(\times 200)$; d An electron micrograph of a portion of a proximal convoluted tubule $50 \mathrm{~min}$ after injection of ${ }^{125} \mathrm{I}-\mathrm{CuZn}$ SOD. The electron-dense condensing vacuoles are heavily labelled, whereas only a few grains are present in the more apical, lucent reabsorption droplets and the microvillar region. The apical structures were more heavily labelled at $10 \mathrm{~min}$ in evidence of the rapid clearance of the protein from the blood via these tubules. $(\times 6,000)$

in the alloxan groups appeared the same as those in the control groups.

Islet cells from animals treated with CuZn SOD or both CuZn SOD and alloxan did not differ from those of control animals. Typical $\beta$ granules (dense, round core with a very thin, lucent rim), $\alpha$ granules (dense core with a wide, lucent rim), and $\delta$ granules (lightly-stained granules with no lucent rim) were visible (Fig. 3). These 
secretory granules were similar in prevalence and structure in control rats and in experimental animals treated with CuZn SOD with and without alloxan. The cisternae of the rough endoplasmic reticulum and Golgi apparatus appeared similar in the latter three groups.

In autoradiographic studies with ${ }^{125} \mathrm{I}$ labelled $\mathrm{CuZn}$ SOD, silver grains were occasionally observed at the electron microscopic level over the plasmalemma of $\beta$ cells and spaces bordering these and other islet cells (Figs. $4 \mathrm{a}$ and $4 \mathrm{~b}$ ). Silver grains were not encountered over cytoplasm or nucleus of any islet cells, indicating failure of labelled enzyme to enter the cell. However, $10-50 \mathrm{~min}$ after injection of iodinated enzyme, radiolabel was evident in great abundance over the proximal convoluted tubules (Fig. 4c). At the ultrastructural level, the grains lay over brush borders and also overlaid forming and condensing reabsorption droplets of proximal renal tubules (Fig. 4d), indicating rapid renal clearance of the injected isotope. Labelling of hepatic Kupffer cells indicated participation also of the reticuloendothelial system in clearance of the enzyme.

\section{Discussion}

The high degree of vulnerability to alloxan of $\beta$ cells in the islets of Langerhans has been known since the reports by Dunn et al. [34, 35]. Our data agree with previous accounts of the selective demise of beta cells after alloxan treatment, showing the expected extensive damage to the fine structure of these cells [e.g. 20,22], particularly at the membrane level [18].

However, we found no ultrastructural evidence for alloxan damage of $\beta$ cells in rats pretreated with $\mathrm{CuZn}$ SOD. The normal abundance and structure of secretion granules in the $\beta$ cells in islets of animals treated with CuZn SOD and alloxan demonstrated that these cells were protected from alloxan by the enzyme. These results provide morphological confirmation of the biochemical data $[5,8,12,13,36]$ indicating that $\mathrm{CuZn}$ SOD prevents the induction of diabetes by alloxan and allows the $\beta$ cells to remain fully functional.

Immunocytochemical staining for islet cell hormones in islets treated with CuZn SOD or with $\mathrm{CuZn}$ SOD and alloxan revealed no change from the normal islet morphology. $\beta$ cells were centrally located with $\alpha$ and $\delta$ cells arranged around the periphery of each islet in both of these experimental groups. These staining patterns observed for the control, CuZn SOD-treated, and $\mathrm{CuZn}$ SOD- and alloxan-treated groups correspond with those reported by Erlandsen et al. [37] for normal rat islets of Langerhans.

The autoradiographic observations showed infrequent silver grains indicative of ${ }^{125} \mathrm{I}$ CuZn SOD location on the plasmalemma of islet cells and in spaces between these cells. Although the grains were so sparse as to make conclusive interpretation difficult, no intracellular grains were encountered and no evidence was ob- tained for SOD entering an islet cell. In preliminary correlated experiments with ${ }^{14} \mathrm{C}$-alloxan, ${ }^{14} \mathrm{C}$ was localized in the cytoplasm of damaged $\beta$ cells (unpublished observations) in agreement with the general perception that alloxan or a metabolite enters the endocrine cells [7]. The apparent failure of labelled SOD to enter $\beta$ cells supports viewing the protective action of the enzyme as an extracellular event. Scavenging of oxygen radicals generated by alloxan at the cell surface may explain the protective action of $\mathrm{CuZn} \mathrm{SOD} \mathrm{against} \mathrm{alloxan-in-}$ duced injury to $\beta$ cells. While it is possible that SOD protected the islets against alloxan via some mechanism unrelated to scavenging of oxygen radicals [ for review see Cooperstein \& Watkins, 38], we feel this to be less likely, since the protective action of CuZn SOD is critically dependent on intact enzyme activity $[12,13]$. The radioautographs also revealed abundant but transitory labelling of resorption droplets in the proximal nephron, and labelling of hepatic Kupffer cells. Rapid clearance of the injected enzyme is, therefore, mediated by a mechanism involving endocytosis and lysosomal degradation of the filtered protein in renal cells and in the reticuloendothelial system.

Acknowledgments. We are grateful to Ms. L. Fussell for assistance with the preparation of the photomicrographs, to Ms. P. Goletz for help with the animal experiments and to Ms. S. Whitehurst for secretarial assistance. This project was supported by NIH grants nos. AM-10956 and EY-03923, grant no. 82R457 from the Juvenile Diabetes. Federation International and grant no. 79 from the United Health \& Medical Research Foundation of South Carolina, Inc.

\section{References}

1. Rerup CC (1970) Drugs producing diabetes through damage of the insulin secreting cells. Pharmacol Rev 22: 485-518

2. Deamer DW, Heikkila RE, Panganamala RV, Cohen G, Cornwell DG (1971) The alloxan-dialuric acid cycle and generation of hydrogen peroxide. Physiol Chem Phys 3: 426-430

3. Cohen G, Heikkila RE (1974) The generation of hydrogen peroxide, superoxide radical, and hydroxyl radical by 6-hydroxydopamine, dialuric acid, and related cytotoxic agents. J Biol Chem 249: $2447-2452$

4. Heikkila RE, Winston B, Cohen G, Barden H (1976) Alloxan-induced diabetes - evidence for hydroxyl radical as a cytotoxic intermediate. Biochem Pharmacol 25: 1085-1092

5. Fischer LJ, Hamburger SA (1980) Inhibition of alloxan action in isolated pancreatic islets by superoxide dismutase, catalase and a metal chelator. Diabetes 29:213-216

6. Ishibashi F, Howard BV (1981) Alloxan and $\mathrm{H}_{2} \mathrm{O}_{2}$ action on glucose metabolism in cultured fibroblasts. Generation of oxygencontaining free radicals as a mechanism of alloxan action. $J$ Biol Chem 256: 12,134-12,139

7. Malaisse WJ (1982) Alloxan toxicity to the pancreatic B-cell. A new hypothesis. Biochem Pharmacol 31: 3527-3534

8. Gandy SE, Galbraith RA, Crouch RK, Buse MG, Galbraith GMP (1981) Superoxide dismutase in human islets of Langerhans. New Engl J Med 304: 1547-1548

9. Crouch RK, Gandy S, Patrick J, Reynolds S, Buse MG, Simson JAV (1984) Localization of copper-zinc superoxide dismutase in the endocrine pancreas. Exp Mol Pathol 41: 377-383

10. Thaete LG, Crouch RK, Schulte BA, Spicer SS (1983) The immunolocalization of copper-zinc superoxide dismutase in canine tissues. J Histochem Cytochem 31: 1399-1406 
11. Grankvist K, Marklund SL, Taljedal I-B (1981) CuZn-superoxide dismutase, Mn-superoxide dismutase, catalase and glutathione peroxidase in pancreatic islets and other tissues in the mouse. Biochem J 199: 393-398

12. Grankvist K, Marklund S, Sehlin J, Taljedal I-B (1979) Superoxide dismutase, catalase and scavengers of hydroxyl radical protect against the toxic action of alloxan on pancreatic islet cells in vitro. Biochem J 182: 17-25

13. Gandy SE, Buse MG, Crouch RK (1982) Protective role of superoxide dismutase against diabetogenic drugs. J Clin Invest 70 : 650-658

14. Buse MG, Gandy SE, Crouch RK (1983) SOD protects B-cells against diabetogenic drugs in rats and isolated canine islets. In: Greenwald RA, Cohen G (eds) Oxy radicals and their scavengers, Vol II. Cellular and medical aspects. Elsevier/North Holland, Amsterdam, pp 119-124

15. Asayama K, Burr IM (1985) Rat superoxide dismutases. Purification, labeling, immunoassay and tissue concentration. $J$ Biol Chem 260: 2212-2217

16. Marklund SL (1984) Extracellular superoxide dismutase in human tissues and human cell lines. J Clin Invest 74: 1398-1403

17. Crouch RK, Gandy SE, Kimsey G, Galbraith RA, Galbraith GMC, Buse MG (1981) The inhibition of islet superoxide dismutase by diabetogenic drugs. Diabetes 30: 235-241

18. Norlund R, Grankvist K, Norlund L, Taljedal IB (1984) Ultrastructure and membrane permeability of cultured pancreatic $\beta$ cells exposed to alloxan or 6-hydroxy-dopamine. Virchows Arch A Pathol Anat 404: 31-38

19. Black HE, Rosenblum IY, Capen CC (1980) Chemically induced (streptozotocin-alloxan) diabetes mellitus in the dog. Biochemical and ultrastructural studies. Am J Pathol 98: 295-310

20. Williamson JR, Lacy PE (1959) Electron microscopy of islet cells in alloxan-treated rabbits. AMA Arch Pathol 67: 102-109

21. Volk BW, Wellmann KF, Lazarus SS (1965) Fine structure of rabbit pancreatic $B$ cells in cortisone-alloxan induced subdiabetes. Lab Invest 14: 1375-1391

22. Wellmann KF, Volk BW, Lazarus SS (1967) Ultrastructural pancreatic beta-cell changes in rabbits after small and large doses of alloxan. Diabetes 16: 242-251

23. Boquist L, Lorentzon R (1979) Stereological study of endoplasmic reticulum, Golgi complex and secretory granules in the $\beta$-cells of normal and alloxan-treated mice. Virch Arch B Cell Pathol 31: 235-241

24. McEvoy RC, Hegre OD (1977) Morphometric quantitation of the pancreatic insulin-, glucagon-, and somatostatin-positive cell populations in normal and alloxan-diabetic rats. Diabetes 26: 1140-1146

25. Boquist $L$ (1968) Alloxan administration in the Chinese hamster. II. Ultrastructural study of degeneration and subsequent regener- ation of the pancreatic islet tissue. Virch Arch B Cell Pathol 1: 169-181

26. Hinkley RE, Burton PR (1970) Fine structure of the pancreatic islet cells of normal and alloxan treated bats (Eptesicus fuscus). Anat Rec 166: 67-86

27. Hunter WM (1973) Radioimmunoassay. In: Weir DM (ed) Handbook of Experimental Immunology (second edition). Blackwell, London, pp 17.1-17.36

28. Beauchamp C, Fridovich I (1971) Superoxide dismutase: improved assays and an assay applicable to acrylamide gels. Anal Biochem 44: 276-287

29. Crouch R, Priest DG, Duke EJ (1978) Superoxide dismutase activities of bovine ocular tissues. Exp Eye Res 27: 503-509

30. Mason TE, Phifer RF, Spicer SS, Swallow RA, Dreskin RB (1969) An immunoglobulin-enzyme bridge method for localizing tissue antigens. J Histochem Cytochem 17: 563-569

31. Hsu S-M, Raine L, Fanger H (1981) The use of avidin-biotin-peroxidase complex (ABC) in immunoperoxidase techniques: a comparison between $\mathrm{ABC}$ and unlabeled antibody (PAP) procedures. J Histochem Cytochem 29: 577-580

32. Thaete LG (1979) Lead and uranium stain artefacts in electron microscopy: a technique for minimizing their occurrence. J Microse 115: 195-201

33. Rogers AW (1979) Techniques of autoradiography, 3rd revised edn. Elsevier/North Holland, Amsterdam

34. Dunn JS, Sheehan HL, McLetchie NGB (1943) Necrosis of islets of Langerhans produced experimentally. Lancet 1: 484-487

35. Dunn JS, Kirkpatrick J, McLetchie NGB, Telfer SV (1943) Necrosis of the islets of Langerhans produced experimentally. J Pathol Bacteriol 55: 245-257

36. Grankvist K, Marklund S, Taljedal I-B (1981) Superoxide dismutase is a prophylactic against alloxan diabetes. Nature 294: $158-160$

37. Erlandsen SL, Hegre OD, Parsons JA, McEvoy RC, Elde RP (1976) Pancreatic islet cell hormones. Distribution of cell types in the islet and evidence for the presence of somatostatin and gastrin within the D cell. J Histochem Cytochem 24: 883-897

38. Cooperstein SJ, Watkins D (1981) Action of toxic drugs on islet cells. In: Cooperstein SJ, Watkins D (eds) The Islets of Langerhans, Academic Press, New York, pp 387-425

Received: 30 November 1983

and in revised form: 20 June 1985

Dr. Samuel S. Spicer

Department of Pathology

Medical University of South Carolina

Charleston, SC 29425 USA 